\title{
DISTRIBUTION, RELATIVE ABUNDANCE AND OCCUPANCY OF SELECTED MAMMALS ALONG PAVED ROAD IN KUBAH NATIONAL PARK, SARAWAK, BORNEO
}

\author{
Jayasilan Mohd-Azlan ${ }^{1}$, Sally S. Kaicheen ${ }^{1}$, Woo C. Yoong ${ }^{1,2}$ \\ ${ }^{1}$ Universiti Malaysia Sarawak, Malaysia \\ e-mail:azlan@unimas.my,sallyskaicheen@hotmail.com \\ ${ }^{2}$ Malaysian Nature Society, Malaysia \\ e-mail:woocheeyoong@gmail.com
}

Received: 31.01.2018

\begin{abstract}
Research on ecological impacts of roads has seldom been studied on Borneo. This includes information on their influence on wildlife dynamic in National Parks and other areas harbouring biodiversity. This knowledge is important to prescribe best management practices, by avoiding, minimising and compensating for adverse impacts such structures may have on individuals, populations and communities. In order to understand the effects of a paved road, located within a protected area (Kubah National Park, Sarawak, western Borneo), on the local mammal species, we set up an array of 20 camera traps using stratified sampling, along a spatial gradient of five distance categories from the road. This ranged from the edge of the road to the interior part of the forests, in the following manner: A) 0-5 m at the edge, B) 5-100 m, C) 100-200 m, D) 200-300 m, and E) 300-400 $\mathrm{m}$. We explored the relationships between the distance to the road with mammalian species richness, and subsequently, for carnivores, ungulates, and Viverridae sp. (civets) and finally, attempted to estimate the density of these animal groups. Camera trap surveys accumulated 2161 camera days, which resulted in 1938 independent animal photos that consisted of 19 species of wild mammals, six species of birds and one reptile species along the gradient. This study suggests that areas close to the road $(0-5 \mathrm{~m})$ are used significantly less than other areas $(\mathrm{n}=8)$, while cameras located within the distance range from 5-100 $\mathrm{m}$ and 100-200 m detected the highest number of species $(n=18)$. The highest numbers of ungulates and members of the family Viverridae (civets) were recorded at 5-100 m, while the distance category 100-200 m recorded the most numbers of carnivores. Several species that could be tolerant to some level of disturbance, such as the leopard cat (Prionailurus bengalensis), banded palm civet (Hemigalus derbyanus), long-tailed porcupine (Trichys fasciculata), and lesser mousedeer (Tragulus kanchil) showed preference at 5-100 m. This might be due to their general diet behaviour and abundance of food resources nearby the forest edge. The findings from this study need to be carefully interpreted as it is based on a small scale project, therefore may not provide information required to quantify and mitigate the negative effects of roads in protected areas. Comprehensive long-term monitoring with appropriate replications, will be required for making appropriate management recommendations for enhancing conservation within the protected areas of Sarawak.
\end{abstract}

Key words: forest edge, forest fragmentation, large mammals, physical barrier, wildlife dynamics

\section{Introduction}

Borneo, world's third largest island, is located in the biodiversity hotspot region of Sundaland (Myers et al., 2000). It is a reservoir of some of the most extensive tropical rain forest in the world, harbouring a rich flora and fauna with high levels of endemism (Taylor et al., 1999; Myers et al., 2000; Koh \& Wilcove, 2008; Brodie et al., 2015a,b). The Bornean rain forests are threatened by rampant forest conversion to oil palm, logging, hunting for bush meat, forest fires and the wildlife trade (Taylor et al., 1999; Bennett et al., 2002; Kinnaird et al., 2003; Sodhi et al., 2004; Nakagawa et al., 2006; Linkie et al., 2007; Gaveau et al., 2014; Brodie et al., 2015b). These have necessitated the establishment of protected areas, such as national parks and nature reserves.
Sarawak, the largest State in Malaysia, have gazetted 56 protected areas since the 1950s which includes 37 national parks (including marine parks), five wildlife sanctuaries, and 14 nature reserves, together forming $9418.014 \mathrm{~km}^{2}$ of protected area system (FDS, 2017). However, intensive logging in Sarawak, that started in the early 1970s may have resulted in many of the recently gazetted national parks with a logging history and often surrounded by plantations or timber concessions (Mathai et al., 2013; Gaveau et al., 2014). Even though a logged forest is able to sustain similar densities of particular species as sufficiently as unlogged forest after more than 10 years, illegal hunting introduced by the presence of logging roads within the forests causes long-term negative impacts on the species richness (Velho et al., 2012; Brodie et al., 2015b). 
Illegal hunting is further aggravated through the expansion of the logging road (Sodhi et al., 2004; Pangau-Adam et al., 2012; Brodie \& Giordano, 2013; Brodie et al., 2015b).

The construction of a road elevates habitat fragmentation, edge effects, population isolation and various other adverse effects to the ecosystem (Strayer et al., 2003; Fahrig \& Rytwinski, 2009; Laurance et al., 2009; Tsuyuki et al., 2011). The road-effect normally induces negative impacts on wildlife population density and diversity while larger terrestrial mammals are especially prone to such changes; namely disrupted animal movement, road kill, habitat loss, altered animal behaviour due to traffic (Andrews, 1990; Clements et al., 2014).

Larger terrestrial mammals are cryptic, elusive, and sensitive, but are often keystone/flagship species known for their importance in maintaining balanced populations and biodiversity in an ecosystem (Kerley et al., 2003; Mohd-Azlan, 2006). In general, their density has been demonstrated to be correlated to distance from roads, with a gradually decline on density of sensitive mammals from the road into the forest with a $5 \mathrm{~km}$ zone (Clements et al., 2014). To date, research regarding long term effects of roads on the ecology of mammals and other wildlife species in south-east Asia's forests, especially Borneo, remains scarce (Clements et al., 2014), including the effect of the existence of roads in protected areas. Here, we examine the occurrence pattern of medium to larger terrestrial mammals along a paved road in a protected area in Sarawak. To date, no research was carried out to investigate the effect of the road leading to Gunung (= Mount) Serapi in Kubah National Park on medium to large terrestrial mammals $(>1 \mathrm{~kg})$. In the light of this, we aim to investigate the occupancy, species richness, and activity pattern of these selected terrestrial mammals along a road entirely located within Kubah National Park, commencing from the main gate to the Park, to the region of the summit, covering a $5 \mathrm{~km}$ length. We suspect that the occupancy and density of mammals will be influenced by the road (Clements et al., 2014).

\section{Material and Methods}

\section{Study Sites}

The study was conducted in Kubah National Park (KNP; N $01^{\circ} 36.761^{\prime}$, E $110^{\circ} 11.822^{\prime}$ ) that lies on Matang ridge, located $22 \mathrm{~km}$ west of Kuching city. The Park boasts an extraordinary numbers of palm species, and various faunal groups, within a $22 \mathrm{~km}^{2}$ area. There are three mountains with plateau sand- storm formation in KNP, the Gunung Serapi with $911 \mathrm{~m}$ a.s.1., Gunung Sendok with $427 \mathrm{~m}$ a.s.l. and Gunung Selang with 396 m a.s.l. (Pearce, 1994; Das et al., 2007). The Park is mostly accessible by public, and comprises patches of Kerangas forests, scrub forests, alluvial as well as ridge-top forests, mostly under the category encompassing mixed dipterocarp forests, while lower montane forests can be observed above $700 \mathrm{~m}$ a.s.l. (Pearce, 1994; Hazebroek \& bin Abang Morshidi, 2000; Das et al., 2007; Dow \& Reels, 2013). Multiple types of soil characterise Kubah National Park (KNP), and consist of soft podzolic soils of different colours (i.e., red-yellow and grey-white), lowland podzols on soft old alluvium, soft upland podzols and concentrated alluvial soils (Pearce, 1994). In Sarawak, KNP is the only Park with a paved tar road that leads to the peak of Gunung Serapi, clearly bisecting the forest. The width of the winding paved road in KNP to the summit is around $3-4 \mathrm{~m}$ and $5 \mathrm{~km}$ in length. This road is used to access the telecommunication and observation tower at the peak. KNP was opened to public in 1998 and attracts approximately 13,000 local and foreign visitors annually. Vehicles of visitors are restricted to the summit trail, while transport of army and telecommunication equipment and personnel are allowed to trek along this road.

\section{Data Collection}

Bushnell ${ }^{\circ}$ Trophy Cam units with passive infrared motion sensors were deployed at 20 subsites within KNP from October 2016 until April 2017 (seven months). Camera traps were set with three photos per trigger, with an interval of two minutes operated for $24 \mathrm{~h}$ throughout the study period. We assumed a distance of $400 \mathrm{~m}$ as a buffer for animals from the paved road in KNP. Camera traps were stratified along a gradient with five distance ranges from the interior part of the forests to the roadside; A) 0-5 $\mathrm{m}$ at the edge, B) 5-100 m, C) 100-200 m, D) 200-300 $\mathrm{m}$ and E) 300-400 $\mathrm{m}$ with four camera sites in each distance range. Camera traps were distributed along animal trails, nearby rivers, ridges or fallen logs from $173 \mathrm{~m}$ a.s.l. to $765 \mathrm{~m}$ a.s.l. in order to maximise the detection rate along the road (Mohd-Azlan \& Engkamat, 2013). Pictures collected were sorted and identified to species level. Detection of the same species regardless of number of individuals at the same camera station are counted as one independent event within $60 \mathrm{~min}$. Time periods were pooled in one hour intervals and activity levels of a species were plotted for species with over 10 independent events. Diurnal activity was categorised from 06:00-18:00 h (Mohd- 
Azlan \& Engkamat, 2013). Analysis was performed based on the percentage of activity level:

$$
\text { Percentage of activity level }=(N t / \Sigma N) \times 100 \% \text {, }
$$

where $N t$ is the total number of photos record at the same hour of the day and $\Sigma N$ is the total number of independent events of the same hour of the day.

\section{Data Analysis}

Data analysis was done using R 3.4.3 software packages. Binary data collected from camera traps with an absence (0) or presence (1) of animals during the sampling period were pooled into seven days per occasion to minimise numbers of zero that count as no detection. The Royle-Nichols model enables to estimate the relative abundance of species/proportion of the area occupied based on the occupancy rate by assuming independency of each detection, constancy for density, and detection probability of that species (Royle \& Nichols, 2003). The Royle-Nichols model can be explained by the following formula:

$$
p_{i}=1-(1-r)^{N_{i}},
$$

where $p_{i}$ is the detection probability for that species at site $i, r$ is probability of detecting at least once that species, and $N_{i}$ is the individual available for detection at site $i$. Distribution of $N_{i}$ is following Poisson distribution with parameter lambda, $\lambda$ as density estimate that can be affected by $r$ in closed population. Detection probability of a species varies with the heterogeneity of abundance. Hence, we only estimate the relative abundance of mammals that detected more than five times throughout the study with a $95 \%$ credible interval (C.I.). Finally, the occupancy matrix of animals may infer its distribution by assuming a closed population where no animals immigrate nor migrate to a new habitat during sampling. We assessed a species occupancy matrix with a single-season model to determine whether occupancy, $\psi$ or/and detection probability, $p$ of species is restricted by the distance of the camera trap location to the paved road (MacKenzie $\&$ Kendall, 2002). The naïve occupancy is the proportion of area occupied by the species. The model with the lowest small sample-size corrected version of Akaike Information Criterion (AICc) value was chosen as the best model. An activity overlap was performed for larger mammals that have independent photos $>10$ at each distance range. Based on times of observation with kernel density estimate, we determined the coefficient of overlap that lay below two density distribution. Dhat 1 is well fitted for small sample size. Therefore it was used in this study (Ridout \& Linkie, 2009).

\section{Results}

Over a period of seven months of consecutive sampling, the study has amounted 2161 camera days. A total of 7362 of photographs were exposed, which is an equivalent to 368 shots per camera deployed. Approximately $74 \%$ of the total photographs could not be utilised due to technical errors and poor angle of animal shots where a species could not be determined. The highest number of unidentified animals are small mammals, missed due to poor image quality. The remaining 1938 photographs $(26 \%)$ showed images of larger terrestrial mammals $(22 \%)$, birds $(3 \%)$, reptiles $(1 \%)$ and humans $(1 \%)$ (Table 1$)$. We have determined 16 genera and at least 19 species of wild mammals, excluding unidentified species of squirrels, rodents and civets recorded by camera trapping in the study area (Table 1). In addition, we have also registered six bird species spending substantial amount of time on the ground. These are emerald dove (Chalcophaps indica (Linnaeus, 1758)), whiterumped shama (Kittacincla malabarica (Scopoli, 1788)), Siberian blue robin (Larvivora cyane (Pallas, 1776)), short-tailed babbler (Trichastoma malaccense (Hartlaub, 1844)), wren babbler (Napothera epilepidota (Temminck, 1827)), and rufous-browed babbler (Pellorneum capistratum (Temminck, 1823)).

The long-tailed porcupine (Trichys fasciculate (Shaw, 1801)) is the most often photographed animal (39\%) followed by the moon rat $(15 \%)$. In contrast, the oriental small-clawed otter (Aonyx cinereus (Illiger, 1815)) was recorded only once during this study at the camera site with distance 200-300 m, at an altitude of $222 \mathrm{~m}$ a.s.1. Camera traps deployed within $0-5 \mathrm{~m}$ of the forest edge were recording the lowest number of species $(n=8)$, while cameras deployed within distances of 5-100 m and 100-200 $\mathrm{m}$ were detecting the highest number of species $(\mathrm{n}=18)$ (Table 1, Fig.). At the distance of 5-100 $\mathrm{m}$, the highest number of ungulates and Viverridae (civets) has been recorded, while the highest number of carnivores has been recorded at the distance of 100-200 m (Fig.). The lesser mousedeer (Tragulus kanchil (Raffles, 1821)), greater mousedeer (Tragulus napu (F. Cuvier, 1822)), bearded pig (Sus barbatus Müller, 1838), leopard cat (Prionailurus bengalensis (Kerr, 1792)) and banded palm civet (Hemigalus derbyanus (Gray, 1837)) were mostly encountered at the distance range 5-100 $\mathrm{m}$ of the forest edge whereas the long-tailed porcupine has mostly been registered at the distance of $0-5 \mathrm{~m}$ of 
the forest edge. The Sunda pangolin (Manis javanica Desmarest, 1822) was recorded only at the distances of $200-300 \mathrm{~m}$ and $300-400 \mathrm{~m}$ of the forest edge with one detection for each distance. The total number of animal captures over all trap days was equivalent to 0.012 . This indicates a relatively low animal activity in the sampling strip. Most animals were photographed alone or in pairs, except for the oriental small-clawed otter (up to three individuals). The expected species richness of medium to large mammals was 17 , while the sampling saturation was relatively high. Of the 27 species recorded, the Sunda pangolin is the only Critically Endangered species, while four species are listed as Vulnerable on the IUCN Red List (IUCN, 2017). This indicates that threatened and locally rare species inhabit the area along this paved road. A total of 16 species do have a protection status. Moreover, approximately $41 \%$ of the species $(n=11)$ are not listed under Sarawak Wild Life Protection Ordinance (SWLPO, 1998). Approximately $89 \%$ of the species $(n=24)$ recorded in the study are not listed in CITES (Convention on International Trade in Endangered Species of Wild Fauna and Flora). Species which are not listed in SWLPO (1998) and Appendices I and II of CITES do not receive any protection outside this reserve. And local communities can hunt them for consumption.

The matrix of data for occupancy of eleven large mammals was structured according to the RoyleNichols model (Table 2). The long-tailed porcupine had the highest estimated mean for occupancy rate in this study with a value of 0.69 (C.I $=0.48-0.87$ ), while the collared mongoose (Herpestes semitorquatus Gray, 1846) is characterised by a least value at 0.10 (C.I $=0.01-0.27$ ). However, for the banded palm civet, the estimated $\lambda$ in Poisson distribution has the highest mean density with $1.36($ C.I. $=0.43-4.21)$ and the highest totalN $=27.23$ (C.I. $=11.00-83.00$ ), while the collared mongoose is characterised as a species with the lowest density 0.11 (C.I. $=0.01-0.32$ ) and the lowest totalN $=2.24$ (C.I. $=2.00-4.00)$ (Table $2)$. The long-tailed porcupine has the highest detection probability with an estimated mean of $r=0.17$ (C.I. $=0.11-0.24)$ whereas the banded palm civet has the least detection probability with an estimated mean of $r=0.04$ (C.I. $=0.01-0.08$ ) even though with the highest totalN. For each camera site within a certain distance range, the estimated mean was evaluated as the highest mean at $0-5 \mathrm{~m}, 300-400 \mathrm{~m}$ for the longtailed porcupine, followed by the lesser mousedeer at 5-100 $\mathrm{m}$, and then for the banded palm civet at $100-200 \mathrm{~m}$ and $200-300 \mathrm{~m}$.

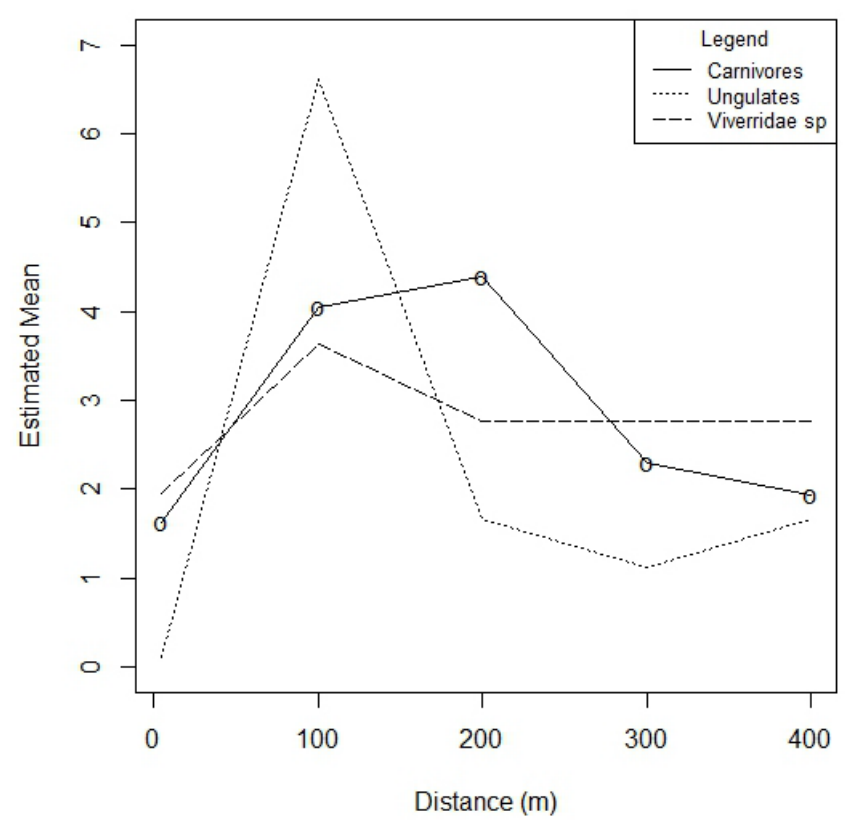

Fig. Estimated mean of animal categories at each distance range along the paved road in Kubah National Park, Sarawak, Borneo.

The long-tailed porcupine was registered throughout the study with the highest naïve occupancy of 0.70 , followed by the banded palm civet with 0.50 and the lesser mousedeer with 0.40 (Table $3)$. Occupancy and detection probability of 13 medium to large mammals were not affected by the distance of the camera trap to the paved road. Yet the occupancy of the short-tailed mongoose (Herpestes brachyurus Gray, 1837), Sunda pangolin and thickspined porcupine (Hystrix crassispinis (Günther, 1877)) was dependent on this parameter. The detection probability values of the lesser mousedeer and the long-tailed porcupine were affected by the distance of the camera trap to the paved road. Neither occupancy nor detection probability of the leopard cat were affected by distance. The relationship between the estimated mean richness of animals (overall species, Viverridae and Ungulates) and the distance has not been determined $(\mathrm{P}>0.05)$.

The coefficient of overlap Dhat 1 for the activity pattern between distance ranges was only estimated for the long-tailed porcupine $(\mathrm{N}>10)$. The longtailed porcupine demonstrated a relatively high coefficient of overlap between distance ranges. The nocturnal activity level of the long-tailed porcupine at the five distance ranges were $98 \%, 100 \%, 93 \%$, $100 \%$, and $97 \%$, respectively. The activity pattern of the long-tailed porcupine at 100-200 $\mathrm{m}$ had the least overlap (Dhat $1=0.79$ ) with the distance of 200-300 m, while the activity pattern was similar from the edge to the distance of $200 \mathrm{~m}$. 
Table 1. List of species registered by camera traps and arranged according to distance range (A: 0-5 m, B: 5-100 m, C: 100-200 m, D: 200-300 m, E: 300-400 m) and their protection and conservation status

\begin{tabular}{|c|c|c|c|c|c|c|c|c|c|}
\hline \multirow{2}{*}{ Species } & \multicolumn{5}{|c|}{ Distance from the road $(\mathrm{m})$} & \multirow{2}{*}{ Total } & \multicolumn{3}{|c|}{ Protection and conservation status } \\
\hline & $0-5$ & $5-100$ & $100-200$ & $200-300$ & $300-400$ & & SWLPO, 1998 & IUCN, 2017 & CITES \\
\hline \multicolumn{10}{|c|}{ Columbidae } \\
\hline $\begin{array}{l}\text { Chalcophaps indica } \\
\text { Emerald Dove }\end{array}$ & - & 1 & 2 & - & 3 & 6 & N/A & $\mathrm{LC}$ & N/A \\
\hline \multicolumn{10}{|c|}{ Muscicapidae } \\
\hline $\begin{array}{l}\text { Kittacincla malabarica } \\
\text { White-Rumped Shama }\end{array}$ & - & 1 & 1 & - & - & 2 & $\mathrm{P}$ & $\mathrm{LC}$ & N/A \\
\hline $\begin{array}{l}\text { Larvivora cyane } \\
\text { Siberian Blue Robin }\end{array}$ & - & 20 & 1 & - & - & 21 & N/A & LC & N/A \\
\hline \multicolumn{10}{|c|}{ Pellorneidae } \\
\hline $\begin{array}{l}\text { Trichastoma malaccense Short-Tailed } \\
\text { Babbler }\end{array}$ & 1 & - & - & 1 & 3 & 5 & N/A & NT & N/A \\
\hline $\begin{array}{l}\text { Napothera epilepidota } \\
\text { Eyebrowed Wren-Babbler }\end{array}$ & - & - & - & - & 1 & 1 & N/A & $\mathrm{LC}$ & N/A \\
\hline $\begin{array}{l}\text { Pellorneum capistratum } \\
\text { Rufous-Browed Babbler }\end{array}$ & 2 & - & - & - & - & 2 & N/A & $\mathrm{LC}$ & N/A \\
\hline \multicolumn{10}{|c|}{ Cervidae } \\
\hline $\begin{array}{l}\text { Muntiacus muntjak } \\
\text { Bornean Red Muntjac }\end{array}$ & - & - & 2 & 1 & - & 3 & N/A & $\mathrm{LC}$ & N/A \\
\hline \multicolumn{10}{|c|}{ Suidae } \\
\hline $\begin{array}{l}\text { Sus barbatus } \\
\text { Bearded pig }\end{array}$ & - & 4 & 3 & - & 2 & 9 & N/A & VU & N/A \\
\hline \multicolumn{10}{|c|}{ Tragulidae } \\
\hline $\begin{array}{l}\text { Tragulus kanchil } \\
\text { Lesser Mousedeer }\end{array}$ & - & 36 & 2 & 1 & 5 & 44 & N/A & $\mathrm{LC}$ & N/A \\
\hline $\begin{array}{l}\text { Tragulus napu } \\
\text { Greater Mousedeer }\end{array}$ & - & 4 & 2 & - & - & 6 & N/A & LC & N/A \\
\hline
\end{tabular}

\title{
Felidae
}

Prionailurus bengalensis Leopard Cat

\section{Herpestidae \\ terpestidae}

Herpestes brachyurus

Short-Tailed Mongoose

Herpestes semitorquatus

Collared Mongoose

\section{Mustelidae}

\author{
Aonyx cinereus \\ Oriental Small-Clawed Otter \\ Mustela nudipes \\ Malay Weasel \\ Arctictis binturong
Binturong/Bearcat \\ Arctogalidia trivirgata \\ Small-Toothed Palm Civet \\ Hemigalus derbyanus \\ Banded Palm Civet \\ Paguma larvata \\ Masked Palm Civet \\ Paradoxurus hermaphroditus \\ Common Palm Civet
}

$\begin{array}{lll}1 & - & 3 \\ - & 2 & 5\end{array}$




\begin{tabular}{|c|c|c|c|c|c|c|c|c|c|}
\hline \multirow{2}{*}{ Species } & \multicolumn{5}{|c|}{ Distance from the road (m) } & \multirow{2}{*}{ Total } & \multicolumn{3}{|c|}{ Protection and conservation status } \\
\hline & $0-5$ & $5-100$ & $100-200$ & 200-300 & $300-400$ & & SWLPO, 1998 & IUCN, 2017 & CITES \\
\hline \multicolumn{10}{|c|}{ Cercopithecidae } \\
\hline $\begin{array}{l}\text { Macaca nemestrina } \\
\text { Pig-Tailed Macaque }\end{array}$ & 1 & 1 & 3 & - & 4 & 9 & $\mathrm{P}$ & VU & N/A \\
\hline \multicolumn{10}{|c|}{ Hystricidae } \\
\hline $\begin{array}{l}\text { Hystrix crassispinis } \\
\text { Thick-Spined Porcupine }\end{array}$ & - & 5 & 3 & 6 & 2 & 16 & $\mathrm{P}$ & $\mathrm{LC}$ & N/A \\
\hline $\begin{array}{l}\text { Hystrix brachyuran } \\
\text { Malayan Porcupine }\end{array}$ & - & - & 2 & - & 3 & 5 & $\mathrm{P}$ & $\mathrm{LC}$ & N/A \\
\hline $\begin{array}{l}\text { Trichys fasciculata } \\
\text { Long-Tailed Porcupine }\end{array}$ & 42 & 33 & 28 & 26 & 37 & 166 & $\mathrm{P}$ & $\mathrm{LC}$ & N/A \\
\hline \multicolumn{10}{|c|}{ Erinaceidae } \\
\hline $\begin{array}{l}\text { Echinosorex gymnura } \\
\text { Moonrat }\end{array}$ & 5 & 33 & 11 & 3 & 12 & 64 & N/A & $\mathrm{LC}$ & N/A \\
\hline \multicolumn{10}{|c|}{ Varanidae } \\
\hline $\begin{array}{l}\text { Varanus rudicollis } \\
\text { Rough-Necked Monitor Lizard }\end{array}$ & - & 2 & - & 2 & 1 & 5 & $\mathrm{P}$ & N/A & II \\
\hline Total of Independent Events & 54 & 165 & 76 & 50 & 80 & 425 & $16 P$ & $\begin{array}{c}17 \mathrm{LC} \\
4 \mathrm{NT} \\
4 \mathrm{VU} \\
1 \mathrm{CR}\end{array}$ & $\begin{array}{l}1 \text { I } \\
3 \text { II }\end{array}$ \\
\hline Total number of species & 8 & 18 & 18 & 14 & 14 & 27 & & & \\
\hline
\end{tabular}

Note: P - Protected; TP - Totally Protected; N/A - Not Protected (SWLPO - Sarawak Wild Life Protection Ordinance, 1998). LC - Least Concern, NT - Near Threatened, VU - Vulnerable, CR - Critically Endangered (International Union for Conservation of Nature (IUCN) Red List of Threatened Species). I - Appendix I, II - Appendix II, III - Appendix III (Convention of International Trade in Endangered Species of Wild Fauna and Flora (CITES) Appendices).

Table 2. List of estimated mean for occupancy (psi), density estimate - lambda $(\lambda)$, detection probability of at least one individual $(r)$, distance ranges $(0-5 \mathrm{~m}, 5-100 \mathrm{~m}, 100-200 \mathrm{~m}, 200-300 \mathrm{~m}, 300-400 \mathrm{~m})$ and total number of individuals available for detection (totalN) with $95 \%$ credible interval

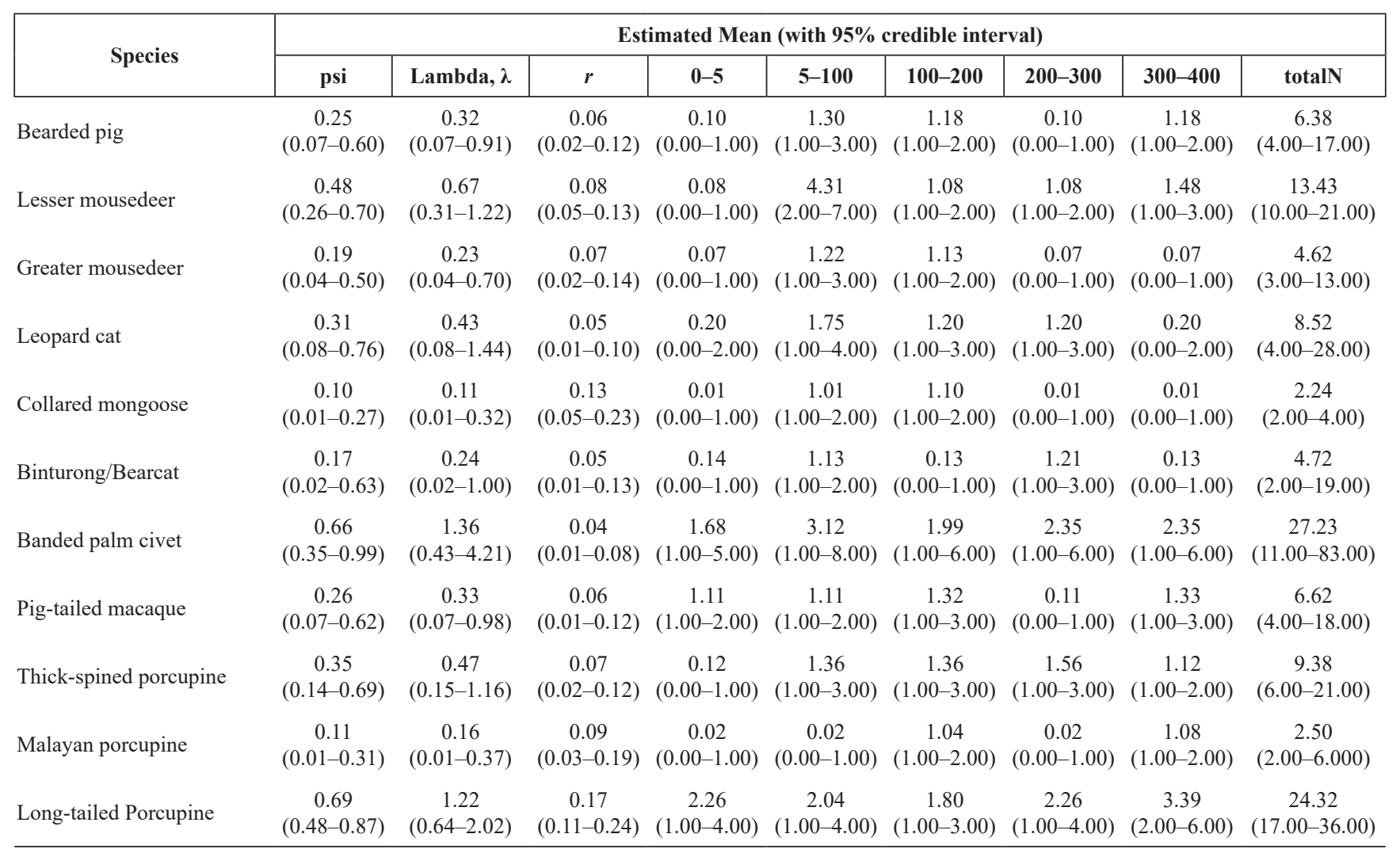


Table 3. List of species with an occupancy model to compare the effect of distance from paved road on occupancy and detection probability of large mammals. Model are arranged in a framework with either a distance variable (D) or model intercept («.») in occupancy (psi) and detection probability (p) functions. Model with 0.00 indicates best model with lowest $\Delta$ AICc

\begin{tabular}{|c|c|c|c|c|c|c|c|c|c|}
\hline \multirow{2}{*}{ Species } & \multirow{2}{*}{$\begin{array}{c}\text { Naïve } \\
\text { Occupancy }\end{array}$} & \multicolumn{2}{|c|}{ psi(.), p(.) } & \multicolumn{2}{|c|}{ psi(D), p(.) } & \multicolumn{2}{|c|}{ psi(.), p(D) } & \multicolumn{2}{|c|}{ psi(D), p(D) } \\
\hline & & $\Delta \mathrm{AICc}$ & Weight & $\Delta \mathrm{AICc}$ & Weight & $\triangle \mathrm{AICc}$ & Weight & $\Delta \mathrm{AICc}$ & Weight \\
\hline Bornean red muntjac & 0.10 & 0.00 & 0.47 & 0.89 & 0.30 & 2.60 & 0.13 & 3.12 & 0.10 \\
\hline Bearded pig & 0.20 & 0.00 & 0.63 & 2.71 & 0.16 & 2.63 & 0.17 & 5.80 & 0.04 \\
\hline Lesser mousedeer & 0.40 & 5.40 & 0.05 & 8.11 & 0.01 & 0.00 & 0.72 & 2.38 & 0.22 \\
\hline Greater mousedeer & 0.15 & 0.00 & 0.41 & 1.80 & 0.17 & 2.05 & 0.15 & 0.82 & 0.27 \\
\hline Leopard cat & 0.20 & 1.55 & 0.24 & 4.01 & 0.07 & 2.13 & 0.18 & 0.00 & 0.52 \\
\hline Short-tailed mongoose & 0.20 & 1.57 & 0.23 & 0.00 & 0.50 & 3.63 & 0.08 & 1.85 & 0.20 \\
\hline Collared mongoose & 0.10 & 0.00 & 0.58 & 2.48 & 0.17 & 2.42 & 0.17 & 4.15 & 0.07 \\
\hline $\begin{array}{l}\text { Oriental small-clawed } \\
\text { otter }\end{array}$ & 0.05 & 0.00 & 0.46 & 1.03 & 0.28 & 2.32 & 0.15 & 2.82 & 0.11 \\
\hline Malay weasel & 0.10 & 0.00 & 0.47 & 0.89 & 0.30 & 2.61 & 0.13 & 3.12 & 0.10 \\
\hline Binturong/Bearcat & 0.10 & 0.00 & 0.59 & 2.79 & 0.15 & 2.15 & 0.20 & 4.23 & 0.07 \\
\hline Small-toothed palm civet & 0.10 & 0.00 & 0.59 & 2.01 & 0.22 & 2.61 & 0.16 & 5.78 & 0.03 \\
\hline Banded palm civet & 0.50 & 0.00 & 0.61 & 2.79 & 0.15 & 2.61 & 0.17 & 4.30 & 0.07 \\
\hline Masked palm civet & 0.10 & 0.00 & 0.54 & 1.84 & 0.21 & 1.96 & 0.20 & 4.97 & 0.05 \\
\hline Common palm civet & 0.10 & 0.00 & 0.44 & 0.64 & 0.33 & 2.42 & 0.13 & 3.20 & 0.09 \\
\hline Sunda pangolin & 0.10 & 0.77 & 0.27 & 0.00 & 0.40 & 1.02 & 0.24 & 3.17 & 0.08 \\
\hline Pig-tailed macaque & 0.20 & 0.00 & 0.46 & 2.60 & 0.13 & 0.70 & 0.32 & 3.15 & 0.10 \\
\hline Thick-spined porcupine & 0.30 & 0.42 & 0.34 & 0.00 & 0.42 & 3.21 & 0.08 & 1.84 & 0.17 \\
\hline Malayan porcupine & 0.10 & 0.00 & 0.38 & 1.67 & 0.16 & 0.02 & 0.38 & 3.09 & 0.08 \\
\hline Long-tailed porcupine & 0.70 & 0.03 & 0.38 & 2.31 & 0.12 & 0.00 & 0.39 & 2.34 & 0.10 \\
\hline
\end{tabular}

\section{Discussion}

Roads in tropical rainforest act as a notorious barrier that fragments the forest, creates edge and impede the movement of animals. It especially affects large mammals, which are sensitive to anthropogenic activities and highly confined to undisturbed habitats (Woodroffe \& Ginsberg, 1998; Strayer et al., 2003; Fahrig \& Rytwinski, 2009; Laurance et al., 2009; Clements et al., 2014; Brodie et al., 2015a). The size of an animal population gradually increases with the distance to a forest depth (Nellemann et al., 2001; Clements et al., 2014) where the density of some animals in the sampling zone of KNP appears to be related to distance (Table 4). Our study has recorded 19 species of large terrestrial mammals within $400 \mathrm{~m}$ from the road. The largest iconic Bornean mammals have not been recorded throughout sampling. These animals are the Sambar Deer (Rusa unicolor (Kerr, 1792)), Sunda Clouded Leopard (Neofelis diardi (G. Cuvier, 1823)) and the Sun Bear (Helarctos malayanus (Raffles, 1821)). An absence of large-bodied mammals near the road raises the question on the tolerance of these species to disturbance by the road. This also infers the secretive, elusive and natural behaviour of large mammals which tend to avoid any anthropogenic activities (Mohd-Azlan \& Sharma, 2006; Garrote et al., 2012; Brodie et al., 2015a). Some of the animals are species of conservation importance, habitat specialists or endemic. They are probably more vulnerable to road effects than other species (Andrews, 1990). So, such species as the Hose's civet (Diplogale hosei (Thomas, 1892)), Bornean bay cat (Catopuma badia (Gray, 1874)) and otter civet (Cynogale bennettii Gray, 1837) have not been recorded throughout the study. We have not recorded species which can tolerate some level of disturbance either: e.g. the Malay civet (Viverra tangalunga Gray, 1832) (Jennings et al., 2010) and long-tailed macaque (Macaca fascicularis (Raffles, 1821)). Most of the species recorded within a road buffer are characterised by possessing a high reproduction ability. They have been registered in forest edges adjacent to an original habitat (Andrews, 1990). 
Although our study has detected 19 species of large mammal species, a detection record and number of recorded terrestrial mammals per effort $(0.008)$ were relatively low compared to Loagan Bunut National Park (0.020) (Mohd-Azlan et al., 2006) and Lambir Hill National Park (0.016) (Mohd-Azlan \& Engkamat, 2006). However, the obtained results are slightly higher than shown in a past study in KNP (0.007) (Mohd-Azlan et al., 2007). The total number of independent photos of large mammals available for detection was mostly below 10 with a low occupancy rate (Tables 1,2$)$. The banded palm civet was statistically considered as a species that is most difficult to detect in Kubah National Park with a low value of $r$ (Table 2). Our data have statistically estimated a small population size of medium and large terrestrial animals within the sampling strip of KNP. The banded palm civet was estimated with the highest density totalN $=27.23$, with credible interval with the highest estimate of 83 individuals, while the collared mongoose has been estimated with the smallest population size at totalN $=2.24$, with credible interval of two to four individuals (Table 2). The bearded pig was represented as a large mammal estimated with approximately 6.38 individuals (C.I. $=4.00-17.00$ ). Such a relatively low estimation may explicit the negative effect of a road on mammals (Clements et al., 2014). Perhaps, the habitat modification along this paved road has affected the demography and reduced the population size of some species over the long-term period since the road establishment (e.g. Kroodsma, 1985; Woodroffe \& Ginsberg, 1998).

The absence of the long-tailed macaque, sparse records of binturong (Arctictis binturong (Raffles, 1821)) and small-toothed palm civet (Arctogalidia trivirgata (Gray, 1832)) could be explained by their arboreal behaviour, when their movements restrained by gaps in the canopies due to the paved road (Laurance et al., 2006). The inhibition of arboreal mammals to cross the paved road can reduce a gene flow and cause a population bottleneck in long term (Andrews, 1990). The detection records of ungulates were relatively low in this study. And they have not been representative as it was expected at forest edges (Table 1, Fig.). This is consistent with Brodie et al. (2015a), who have not recorded ungulates nearby edges of logged or primary forests. It was suggested that these species may have been affected by anthropogenic activities along this paved road. The relatively higher number of records of the leopard cat, banded palm civet, long-tailed porcupine and lesser mousedeer at a distance of 5-100 $\mathrm{m}$ to the paved road could be due to their general diet behaviour and the abundance of smaller mammals nearby the forest edge (Mohamed et al., 2013; Khorozyan et al., 2014; Brodie et al., 2015a). The occurrence of a species with specialised diet, the Sunda pangolin, was only recorded at the distance of 200-400 $\mathrm{m}$ to the paved road. This may be evidence of its evasion of human activities and traffic noise.

Forest edges within or surrounding the protected area can act as a weak sink to protect large terrestrial mammals, especially large carnivores, from local extinction or population isolation (Woodroffe \& Ginsberg, 1998). The highest estimated mean for carnivores within the sampling strip was within a distance of 5-100 $\mathrm{m}$ to the paved road. It suggests that the small carnivores may venture closer to a road to seek for smaller prey animals. $70 \%$ of the occupancy and detection probability of detected large mammals are not strongly influenced by distance. However, it is significant that detection records of nocturnal mammals are relatively higher than mammals with crepuscular activity. This could be explained by the little human activity in KNP along the road during a night. The discrepancy of activity pattern along the gradient of distance ranges could be further investigated for other species in future studies.

\section{Conclusions}

Although the road in the Kubah National Park (KNP) has not been paved for logging or heavy traffic, the inimical effects of such modifications are not negligible despite of the low occupancy and detection rate of large terrestrial mammals. And it warrants further study. Perhaps, the paved road in KNP has formed a barrier between microhabitats and it has caused edge effects. An expansion of the road network in Sarawak is envisaged as precursor of habitat destruction, illegal hunting, forests fragmentation and potentially affecting the demography of species of conservation importance. The effects along roads cutting across relatively undisturbed habitats on species of conservation importance require further study under conditions of the expansion of major road network ongoing with construction of the pan Borneo highway (from the western tip of Sarawak to Tawau, Sabah in North Borneo).

\section{Acknowledgements}

We would like to express our gratitude to the Ministry of Higher Education, the Government of Malaysia under 
Niche Research Grant Scheme (NRGS/1087/2013(01)) for funding. Sarawak Forestry Department for allowing this research (Permit number NCCD.907.4.4 (JLD.13)-219; park permit number WL009/2016). Sarawak Forestry Corporation for the support and co-operation from park warden, Mr Stephen Antang and park rangers from Kubah National Park. We thank Nurul Asna Hidayah and Marius Joscha Maiwald, UNIMAS, for their assistance. We would also like to show our gratitude to Professor Dr. Indraneil Das, Institute of Biodiversity and Environmental Conservation, UNIMAS, and anonymous reviewers for the reviews and comments that greatly improved the manuscript. Lastly, we also would like to thank the continuous support from the Programme of Animal Resource Science and Management and Universiti Malaysia Sarawak (UNIMAS).

\section{References}

Andrews A. 1990. Fragmentation of habitat by roads and utility corridors: a review. Australian Zoologist 26(34): 130-141. DOI: 10.7882/AZ.1990.005

Bennett E.L., Milner-Gulland E., Bakarr M., Eves H.E., Robinson J.G., Wilkie D.S. 2002. Hunting the world's wildlife to extinction. Oryx, 36(4): 328-329. DOI: 10.1017/ S0030605302000637

Brodie J., Giordano A. 2013. Lack of trophic release with large mammal predators and prey in Borneo. Biological Conservation 163: 58-67. DOI: 10.1016/j.biocon.2013.01.003

Brodie J., Giordano A.J., Ambu L. 2015a. Differential responses of large mammals to logging and edge effects. Mammalian Biology - Zeitschrift für Säugetierkunde 80(1): 7-13. DOI: 10.1016/j.mambio.2014.06.001

Brodie J., Giordano A.J., Zipkin E.F., Bernard H., MohdAzlan J., Ambu L. 2015b. Correlation and persistence of hunting and logging impacts on tropical rainforest mammals. Conservation Biology 29(1): 110-121. DOI: 10.1111/cobi.12389

Clements G.R., Lynam A.J., Gaveau D., Yap W.L., Lhota S., Goosem M., Laurance S.,. Laurance W.F. 2014. Where and how are roads endangering mammals in Southeast Asia's forests? PloS ONE 9(12): e115376. DOI: 10.1371/journal.pone.0115376

Das I., Jankowski A., Makmor M., Haas A. 2007. Species diversity, elevational distribution and reproductive modes in an amphibian community at the Matang Range, Sarawak (Borneo). Mitteilungen Hamburgisches Zoologisches Museum und Institut 104: 141-174.

Dow R.A., Reels G.T. 2013. Previously unpublished Odonata records from Sarawak, Borneo. Part I. Kuching Division excluding Kubah National Park, and Samarahan Division. Faunistic Studies in South-East Asian and Pacific Island Odonata 3: 1-25.

Fahrig L., Rytwinski T. 2009. Effects of roads on animal abundance: an empirical review and synthesis. Ecology and Society 14(1): 21. Available from: https://www.ecologyandsociety.org/vol14/iss1/art21/
FDS. 2018. Nature Conservation \& Constitution. Official Website of Forestry Department Sarawak. Available from: http://www.forestry.sarawak.gov.my/

Garrote G., Gil-Sánchez J.M., McCain E.B., de Lillo S., Tellería J.L., Simón M.Á. 2012. The effect of attractant lures in camera trapping: a case study of population estimates for the Iberian lynx (Lynx pardinus). European Journal of Wildlife Research 58(5): 881-884. DOI: 10.1007/s10344-012-0658-7

Gaveau D.L., Sloan S., Molidena E., Yaen H., Sheil D., Abram N.K., Ancrenaz M., Nasi R., Quinones M., Wielaard N., Meijaard E. 2014. Four decades of forest persistence, clearance and logging on Borneo. PloS ONE 9(7): e101654. DOI: 10.1371/journal.pone.0101654

Hazebroek H.P., bin Abang Morshidi K. 2000. National parks of Sarawak. Kota Kinabalu: Natural History Publications (Borneo). P. 347-379.

IUCN. 2017. The IUCN Red List of Threatened Species. Version 2017-3. Available from http://www.iucnredlist.org. Retrieved on 01 May 2018.

Jennings A.P., Zubaid A., Veron G. 2010. Ranging behaviour, activity, habitat use, and morphology of the Malay civet (Viverra tangalunga) on Peninsular Malaysia and comparison with studies on Borneo and Sulawesi. Mammalian Biology - Zeitschrift für Säugetierkunde 75(5): 437-446. DOI: 10.1016/j.mambio.2009.10.002

Kerley G.I., Pressey R.L., Cowling R.M., Boshoff A.F., SimsCastley R. 2003. Options for the conservation of large and medium-sized mammals in the Cape Floristic Region hotspot, South Africa. Biological Conservation 112(12): 169-190. DOI: 10.1016/S0006-3207(02)00426-3

Khorozyan I., Stanton D., Mohammed M., Al-Ra'il W., Pittet M. 2014. Patterns of co-existence between humans and mammals in Yemen: some species thrive while others are nearly extinct. Biodiversity and Conservation 23(8), 1995-2013. DOI: 10.1007/s10531-014-0700-Z

Kinnaird M.F., Sanderson E.W., O’Brien T.G., Wibisono H.T., Woolmer G. 2003. Deforestation trends in a tropical landscape and implications for endangered large mammals. Conservation Biology 17(1): 245-257. DOI: 10.1046/j.1523-1739.2003.02040.x

Koh L.P., Wilcove D.S. 2008. Is oil palm agriculture really destroying tropical biodiversity? Conservation Letters 1(2): 60-64. DOI: 10.1111/j.1755263X.2008.00011.x

Kroodsma R.L. 1985. Assessing the loss of wildlife habitat in environmental impact statements. Wildlife Society Bulletin (1973-2006) 13(1): 82-87.

Laurance W.F., Croes B.M., Tchignoumba L., Lahm S.A., Alonso A., Lee M.E., Campbell P., Ondzeano C. 2006. Impacts of Roads and Hunting on Central African Rainforest Mammals. Conservation Biology 20(4), 12511261. DOI: 10.1111/j.1523-1739.2006.00420.x

Laurance W.F., Goosem M., Laurance S.G.W. 2009. Impacts of roads and linear clearings on tropical forests. 
Trends in Ecology \& Evolution 24(12): 659-669. DOI: 10.1016/j.tree.2009.06.009

Linkie M., Dinata Y., Nugroho A., Haidir I.A. 2007. Estimating occupancy of a data deficient mammalian species living in tropical rainforests: sun bears in the Kerinci Seblat region, Sumatra. Biological Conservation 137(1): 20-27. DOI: 10.1016/j.biocon.2007.01.016

MacKenzie D.I., Kendall W.L. 2002. How should detection probability be incorporated into estimates of relative abundance? Ecology 83(9): 2387-2393. DOI: 10.1890/0012-9658(2002)083[2387:HSDPBI12.0.CO;2

Mathai J., Jathanna D., Duckworth J. 2013. How useful are transect surveys for studying carnivores in the tropical rainforests of Borneo? The Raffles Bulletin of Zoology 28: 9-12.

Mohamed A., Sollmann R., Bernard H., Ambu L.N., Lagan P., Mannan S., Hofer H., Wilting A. 2013. Density and habitat use of the leopard cat (Prionailurus bengalensis) in three commercial forest reserves in Sabah, Malaysian Borneo. Journal of Mammalogy 94(1): 82-89. DOI: 10.1644/11-MAMM-A-394.1

Mohd-Azlan J. 2006. Mammal diversity and conservation in a secondary forest in Peninsular Malaysia. Biodiversity and Conservation 15(3): 1013-1025. DOI: 10.1007/ s10531-004-3953-0

Mohd-Azlan J., Engkamat L. 2006. Camera Trapping and Conservation in Lambir Hills National Park, Sarawak. The Raffles Bulletin of Zoology 54(2): 469-475.

Mohd-Azlan J., Engkamat L. 2013. Camera Trapping And Conservation In Lanjak Entimau Wildlife Sanctuary, Sarawak, Borneo. The Raffles Bulletin of Zoology 61(1): 397-405.

Mohd-Azlan J., Lisa D.P.A., Engkamat L., Mohidin R. 2007. Camera trapping and conservation in Kubah National Park. In: Proceedings of the $8^{\text {th }}$ Hornbill Workshop on Protected Areas and Biodiversity Conservation. Telang Usang, Sarawak: Sarawak Forestry Corporation. P. 87-101.

Mohd-Azlan J., Sharma D.S. 2006. The diversity and activity patterns of wild felids in a secondary forest in Peninsular Malaysia. Oryx 40(1): 36-41. DOI: 10.1017/ S0030605306000147

Mohd-Azlan J., Tuen A.A., Khombi M., Sait I., Abdullah M.T. 2006. Diversity and abundance of mammals in Loagan Bunut National Park. In: A.A. Tuen, A.K. Sayok, A.N. Toh, G.T. Noweg (Eds.): Scientific Journey through Borneo, Loagan Bunut, PSF Technical Series №5. UNDP, GEF, IBEC, UNIMAS. P. 173-182.

Myers N., Mittermeier R.A., Mittermeier C.G., da Fonseca G.A.B., Kent J. 2000. Biodiversity hotspots for con- servation priorities. Nature 403(6772): 853-858. DOI: $10.1038 / 35002501$

Nakagawa M., Miguchi H., Nakashizuka T. 2006. The effects of various forest uses on small mammal communities in Sarawak, Malaysia. Forest Ecology and Management 231(1-3): 55-62. DOI: 10.1016/j.foreco.2006.05.006

Nellemann C., Vistnes I., Jordhøy P., Strand O. 2001. Winter distribution of wild reindeer in relation to power lines, roads and resorts. Biological Conservation 101(3): 351-360. DOI: 10.1016/S0006-3207(01)00082-9

Pangau-Adam M., Noske R., Muehlenberg M. 2012. Wildmeat or bushmeat? Subsistence hunting and commercial harvesting in Papua (West New Guinea), Indonesia. Human Ecology 40(4): 611-621. DOI: 10.1007/ s10745-012-9492-5

Pearce K. 1994. The palms of Kubah National Park, Kuching Division, Sarawak [Malaysia]. Malayan Nature Journal 48: 1-36.

Ridout M.S., Linkie M. 2009. Estimating overlap of daily activity patterns from camera trap data. Journal of Agricultural, Biological, and Environmental Statistics 14(3): 322-337. DOI: 10.1198/jabes.2009.08038

Royle J.A., Nichols J.D. 2003. Estimating abundance from repeated presence-absence data or point counts. Ecology 84(3): 777-790. DOI: 10.1890/0012-9658(2003)084[0777:EAFRPA]2.0.CO;2

Sodhi N.S., Koh L.P., Brook B.W., Ng P.K. 2004. Southeast Asian biodiversity: an impending disaster. Trends in Ecology \& Evolution 19(12): 654-660. DOI: 10.1016/j.tree.2004.09.006

Strayer D.L., Power M.E., Fagan W.F., Pickett S.T., Belnap J. 2003. A classification of ecological boundaries. BioScience 53(8): 723-729. DOI: 10.1641/0006-3568(2003)053[0723:ACOEB]2.0.CO;2

Taylor D., Saksena P., Sanderson P.G., Kucera K. 1999. Environmental change and rain forests on the Sunda shelf of Southeast Asia: drought, fire and the biological cooling of biodiversity hotspots. Biodiversity \& Conservation 8(9): 1159-1177. DOI: 10.1023/A:1008952428475

Tsuyuki S., Goh M.H., Teo S., Kamlun K., Phua M. 2011. Monitoring deforestation in Sarawak, Malaysia using multitemporal Landsat data. Kanto Forest Research 62: 87-90.

Velho N., Karanth K.K., Laurance W.F. 2012. Hunting: A serious and understudied threat in India, a globally significant conservation region. Biological Conservation 148(1): 210-215. DOI: 10.1016/j.biocon.2012.01.022

Woodroffe R., Ginsberg J.R. 1998. Edge effects and the extinction of populations inside protected areas. Science 280(5372): 2126-2128. DOI: 10.1126/science. 280.5372 .2126 


\title{
РАСПРОСТРАНЕНИЕ, ОТНОСИТЕЛЬНОЕ ОБИЛИЕ И РАЗМЕЩЕНИЕ НЕКОТОРЫХ МЛЕКОПИТАЮЩИХ ВДОЛЬ АСФАЛЬТИРОВАННОЙ ДОРОГИ В НАЦИОНАЛЬНОМ ПАРКЕ «КУБАХ», САРАВАК, БОРНЕО
}

\author{
Д. Мохд-Азлан ${ }^{1}$, С. С. Каичеен ${ }^{1}$ В. Ч. Йоонг ${ }^{1,2}$ \\ ${ }^{1}$ Малазийский университет Саравака, Малайзия \\ e-mail:azlan@unimas.my,sallyskaicheen@hotmail.com \\ ${ }^{2}$ Общество Природы Малайзии, Малайзия \\ e-mail: woocheeyoong@gmail.com
}

\begin{abstract}
Исследования экологических воздействий дорог на Борнео редки. Они включают информацию о влиянии дорог на динамику объектов дикой природы в национальных парках и других охраняемых территориях. Эти данные важны для определения более оптимальных методов управления, избегая, сводя к минимуму и компенсируя неблагоприятные последствия, которые могут иметь такие структуры для отдельных особей, популяций и сообществ. Чтобы понять влияние асфальтированной дороги, расположенной на охраняемой территории (национальный парк Кубах, Саравак, западная часть Борнео) на местных млекопитающих мы установили 20 фотоловушек с использованием стратифицированной выборки вдоль пространственного градиента с пятью вариантами расстояния до дороги. Расстояние от края дороги в глубину лесного массива варьировало следующим образом: А) 0-5 м до края дороги, В) 5-100 м, С) 100-200 м, D) 200-300 м, E) 300-400 м. Мы исследовали зависимость видового богатства млекопитающих от расстояния до дороги, а также отдельно для хищных, копытных животных и Viverridae sp. (циветт) и, наконец, попытались оценить плотность этих групп животных. Исследование включило 2161 фотоловушко-сутки. В результате было получено 1938 независимых фотографий животных, на которых зарегистрировано 19 видов млекопитающих, шесть видов птиц и один вид рептилий. Настоящее исследование предполагает, что области, прилежащие к дороге (0-5 м), используются животными значительно меньше, чем другие области $(\mathrm{n}=8)$. В то же время фотоловушки, расположенные на расстоянии в 5-100 м и 100-200 м, зафиксировали наибольшее количество видов ( $=18)$. Наибольшее количество копытных и цивет (Viverridae spp.) было зарегистрировано на расстоянии 5-100 м от дороги, а на дистанции в 100200 м было зафиксировано наибольшее количество хищных животных. Некоторые виды, которые могут быть устойчивыми к некоторому уровню беспокойства (бенгальская кошка (Prionailurus bengalensis), полосатая циветта (Hemigalus derbyanus), длиннохвостый дикобраз (Trichys fasciculata), и азиатский оленек (Tragulus kanchil)) показали приуроченность к расстоянию в 5-100 м. Это может быть связано с их пищевым поведением и обилием пищи вблизи края леса. Результаты этого исследования требуют тщательной интерпретации, поскольку оно основано на небольшом проекте. Поэтому оно может не представлять информацию, необходимую для количественной оценки и смягчения негативных последствий дорог на всех особо охраняемых природных территориях. Необходим комплексный долгосрочный мониторинг с соответствующими повторностями для принятия соответствующих рекомендаций по управлению для улучшения сохранения биоразнообразия на особо охраняемых природных территориях Саравака.
\end{abstract}

Ключевые слова: динамика объектов дикой природы, край леса, крупные млекопитающие, физическое препятствие, фрагментация леса 